\title{
Outbreak of leptospirosis among canyoning participants, Martinique, 2011
}

P Hochedez (patrick.hochedez@chu-fortdefrance.fr) ${ }^{1}$, M Escher $^{2,3}$, H Decoussy ${ }^{4}$, L Pasgrimaud5, R Martinez ${ }^{5}$, J Rosine ${ }^{2}, R$

Théodose $^{6}$, P Bourhy $^{7}$, M Picardeau $^{7}$, C Olive $^{6}$, M Ledrans $^{2}$, A Cabié $^{1,8}$

1. Infectious and Tropical Diseases Unit, Fort-de-France University Hospital, Martinique, France

2. Regional Office of the French Institute for Public Health Surveillance, Fort-de-France, Martinique, France

3. European Programme for Intervention Epidemiology Training (EPIET), Stockholm, Sweden

4. French Armed Forces in the French West Indies, Fort-de-France, Martinique, France

5. Department of Medicine, Trinité Hospital, Trinité, Martinique, France

6. Laboratory for Microbiology, Fort-de-France University Hospital, Martinique, France

7. National Reference Center and the WHO Collaborating Center for Leptospirosis, Institut Pasteur, Paris, France

8. INSERM CIE 802/Antilles-Guyane University EA 4537, Martinique, France

Two gendarmes who participated in canyoning activities on 27 June 2011 on the Caribbean island of Martinique were diagnosed with leptospirosis using quantitative real-time polymerase chain reaction (qPCR), 9 and 12 days after the event. Among the 45 participants who were contacted, 41 returned a completed questionnaire, of whom eight met the outbreak case definition. The eight cases sought medical attention and were given antibiotics within the first week after fever onset. No severe manifestations of leptospirosis were reported. In seven of the eight cases, the infection was confirmed by qPCR. Three pathogenic Leptospira species, including L. kmetyi, were identified in four of the cases. None of the evaluated risk factors were statistically associated with having developed leptospirosis. Rapid diagnostic assays, such as qPCR, are particularly appropriate in this setting - sporting events with prolonged fresh-water exposure - for early diagnosis and to help formulate public health recommendations. Participants in such events should be made specifically aware of the risk of leptospirosis, particularly during periods of heavy rainfall and flooding.

\section{Introduction}

Over the past few decades, sporting events in tropical areas have become increasingly popular among travellers and athletes. At the same time, leptospirosis outbreaks following exposure to leptospires during recreational water activities, such as swimming, canoeing, kayaking or rafting, have been increasingly reported [1-5]. In Martinique - a Caribbean island and French overseas department and region with a tropical climate - we previously reported a leptospirosis outbreak among participants in a race that took place in the tropical forest after unusually heavy seasonal rainfalls [6].
Leptospirosis is a bacterial zoonosis, distributed worldwide, whose incidence is higher in the tropics, where transmission conditions are favourable. Many wild and domestic animals serve as reservoirs for pathogenic Leptospira strains. Humans are usually infected through abraded skin or mucous membranes in contact with water or soil contaminated by the urine of animal Leptospira reservoirs and, less frequently, by direct contact with infected animals or their urine. Heavy rainfall and flooding strongly increase human exposure to leptospires-contaminated water [7-9]. After a mean incubation period of 10 days (range: $2-30$ ), clinical manifestations are protean and the spectrum of symptoms ranges from subclinical or mild, anicteric, febrile disease to multiorgan involvement associated with high mortality $[8,10]$. Asymptomatic infection is common and may occur in up to $60-70 \%$ of infected individuals, as was reported for serologically identified infections during a 1995 epidemic in Nicaragua and a 1999 outbreak in Thailand [11,12].

At present, although the microscopic agglutination test (MAT) and culture are the gold standard for diagnosis, only direct detection methods using polymerase chain reaction $(P C R)$ can provide a rapid diagnosis during the early, acute stage of the disease $[6,8]$. Although the potential benefit of antibiotic treatment for leptospirosis has not been fully established by randomised placebo-controlled trials, antibiotics may at least decrease the duration of illness and they are commonly used to treat laboratory-diagnosed or even clinically suspected leptospirosis, whether mild or severe $[8,9,13,14]$.

\section{Outbreak detection}

During 10 to18 July 2011, six adults presented at Trinité Hospital, on the east coast of Martinique, with fever associated with chills, headache, myalgia, elevated liver-enzyme levels, leukocytosis and 
thrombocytopenia. During that period, two of them were diagnosed with leptospirosis, which was confirmed by quantitative real-time polymerase chain reaction (qPCR) based on the amplification of pathogenic Leptospira spp. in blood samples. The six patients were part of a group of 45 gendarmes, from a branch of the French Armed Forces, who had participated in a series of three canyon-rescue training exercises along the Absalon River between 27 and 30 June 2011. This river, located in the tropical forest, is very popular for canyoning activities.

Military medical officers notified the regional office of the French Institute for Public Health Surveillance (Institut de Veille Sanitaire, InVS) of these cases on 19 July. Immediately, an investigation was initiated in cooperation with the Department of Infectious Diseases of Fort-de-France Hospital, with the aim of: (i) informing all the participants of the potential risk of leptospirosis and the need to seek medical care if ill; (ii) assessing the magnitude of the outbreak; and (iii) identifying the risk factors and protective measures to be taken in order to make relevant public health recommendations. We report on the results of this investigation and discuss recommendations for preventing leptospirosis.

\section{Methods}

\section{Epidemiological investigation}

A list of all participants in the training exercises was obtained from the military medical officers. By the end of July, a letter, sent to all participants, informed them of their possible exposure to leptospirosis during their recent canyoning activities. They were advised to seek medical attention should they develop a fever (temperature greater than $37.8^{\circ} \mathrm{C}$ ) associated with two or more of the following symptoms or signs: chills, headache, muscle aches, joint aches, conjunctivitis, cough, diarrhoea or haemorrhaging. Accompanying the letter was a standardised questionnaire designed to obtain socio-demographic information (symptoms, specific activities and behaviour during canyoning - e.g. length of stay in the canyon, skin lesions, swallowing any river water, type of protective clothing worn during canyoning), possible exposure since 1 June (e.g. exposures associated with leisure or professional activities, contact with animals, gardening and any type of freshwater exposure) and previous antibiotic use. Moreover, the participants were asked if they had any knowledge of the risk of aquiring leptopirosis before their involvement in the activities. For those who sought medical attention, more detailed clinical information was obtained by reviewing medical records.

\section{Outbreak case definition}

A suspected case of leptospirosis was defined as a person having participated in one of the three canyoning activities and who reported a fever during 27 June to 30 July 2011, along with two or more of the above-mentioned symptoms.
A laboratory-confirmed case of leptospirosis required at least one of the following criteria: (i) positive qPCR; (ii) culture isolation of Leptospira; or (iii) positive MAT.

In this report, we use the term 'cases' to include suspected and laboratory-confirmed cases.

Non-cases were asymptomatic or pauci-symptomatic participants.

\section{Laboratory investigation}

Serum samples were obtained from participants who met the suspected case definition and who underwent a physical examination. Laboratory studies were performed by the Microbiology Unit of Fort-de-France Hospital (qPCR, culture and environmental investigation), and the National Reference Center and the WHO Collaborating Center for Leptospirosis at the Institut Pasteur, Paris, France (enzyme-linked immunosorbent assay (ELISA), MAT and genomic characterisation of Leptospira spp.).

Blood samples collected in ethylenediaminetetraacetic acid (EDTA) tubes obtained from patients during their first week of symptoms were tested by qPCR. After first concentrating the bacteria, DNA was extracted using the QIAamp DNA Mini Kit (Qiagen SA, Courtaboeuf, France). Then qPCR was performed on an $\mathrm{iQTM}_{5}$ realtime PCR detection system (Bio-Rad Laboratories, Marnes-la-Coquette, France) using the DNA-binding dye technique (SYBR Green). The primer set consisting of LFB1-F (5' CATTCATGTTTCGAATCATTTCAAA 3') and LFB1-R (5' GGCCCAAGTTCCTTCTAAAAG 3') used target DNA from pathogenic leptospires and amplified a 331 base pair (bp) fragment [15]. To control for DNA extraction and to detect the presence of PCR inhibitors in DNA extracts, we amplified a fragment of the hypoxanthinephosphoribosyl-transferase (HPRT), as an internal control. A PCR was considered as negative when we were not able to detect the target PCR product but able to detect the PCR internal-control product.

A partial sequence of the Leptospira rrs gene from positive blood samples was amplified by nested-PCR using Taq polymerase and primers $A / B$, then $C / R_{4}[16,17]$. Sequencing was performed at the Genotyping of Pathogens and Public Health Platform (Institut Pasteur, Paris, France) and sequences were aligned in GenBank using the Basic Local Alignment Search Tool (BLAST) to identify the species.

Blood samples were tested at the Institut Pasteur with an in-house IgM ELISA and MAT using 24 antigens. Serovars included in the MAT screening panel were based on prior knowledge of regional epidemiology (Table 1). For MAT, a titre greater than 100 against any of the pathogenic antigens was considered positive if a patient's origin was from a non-endemic area. For patients living in an endemic area, such as the 
TABLE 1

Panel of Leptospira serogroups used in microscopic agglutination testing, leptospirosis outbreak among canyoning participants, Martinique, 2011

\begin{tabular}{|c|c|c|c|}
\hline Leptospira species & Serogroup & Serovar & Strain \\
\hline L. interrogans & Australis & Australis & Ballico \\
\hline L. interrogans & Autumnalis & Autumnalis & Akiyami A \\
\hline L. interrogans & Bataviae & Bataviae & Van Tienen \\
\hline L. interrogans & Canicola & Canicola & Hond Utrecht IV \\
\hline L. borgpetersenii & Ballum & Castellonis & Castellon 3 \\
\hline L. kirschneri & Cynopteri & Cynopteri & $3522 \mathrm{C}$ \\
\hline L. kirschneri & Grippotyphosa & Grippotyphosa & Moskva V \\
\hline L. interrogans & Sejroe & Hardjobovis & Sponselee \\
\hline L. interrogans & Hebdomadis & Hebdomadis & Hebdomadis \\
\hline L. interrogans & Icterohaemorrhagiae & Copenhageni & Wijnberg \\
\hline L. noguchii & Panama & Panama & CZ $214 \mathrm{~K}$ \\
\hline L. biflexa & Semaranga & Patoc & Patoc 1 \\
\hline L. interrogans & Pomona & Pomona & Pomona \\
\hline L. interrogans & Pyrogenes & Pyrogenes & Salinem \\
\hline L. borgpetersenii & Sejroë & Sejroë & M 84 \\
\hline L. borgpetersenii & Tarassovi & Tarassovi & Mitis Johnson \\
\hline L. interrogans & Icterohaemorrhagiae & Icterohaemorrhagiae & Verdun \\
\hline L. weilii & Celledoni & ND & 2011/01963 \\
\hline L. interrogans & Djasiman & Djasiman & Djasiman \\
\hline L. borgpetersenii & Mini & ND & $2008 / 01925$ \\
\hline L. weilii & Sarmin & Sarmin & Sarmin \\
\hline L. santarosai & Shermani & Shermani & $1342 \mathrm{~K}$ \\
\hline L. borgpetersenii & Javanica & Javanica & Poi \\
\hline L. noguchii & Louisiana & Louisiana & LUC1945 \\
\hline
\end{tabular}

ND: Not determined.

Caribbean, a titre of 400 was used, given possible past exposure.

Leptospira spp. were cultured by inoculating $1 \mathrm{ml}$ of heparinised plasma into $10 \mathrm{ml}$ of EllinghausenMcCullough-Johnson-Harris (EMJH) media, which were incubated at $30{ }^{\circ} \mathrm{C}$ and observed weekly for growth for two months.

\section{Environmental investigation}

The Absalon River receives run-off from several houses and some family-owned livestock farms. Surface water samples collected from the river, three and seven weeks after the last training exercise were passed through 0.22 micron filters to remove potential environmental contaminants and were cultured in EMJH media for the presence of leptospires. The filters were crushed and incubated overnight in distilled water. DNA was extracted from the supernatant and $q P C R$ were performed using the protocol described above.

Weather data, including the amount of rainfall during June 2011 in Martinique, were obtained from Météo France, the French national meteorological service.

\section{Statistical analysis}

Exposure information and clinical data and laboratory results, when available, were entered into EpiData version.3.1 and analysed with Stata version 9.0 software (College Station, Texas, United States). Categorical variables were expressed as numbers (\%) and continuous variables as medians (range).

The relationships between case status (cases versus non-cases) and risk factors were tested in univariate analyses using Fisher's exact test and the MannWhitney $U$ test. A p value $<0.05$ defined significance. The effect of each exposure variable was quantified by estimating the relative risk (RR) and its respective $95 \%$ confidence interval $(\mathrm{Cl})$.

\section{Results}

\section{Epidemiological investigation}

Among 45 participants in the canyon-rescue training exercises, 41 returned a completed questionnaire. Of these, 39 were male; their median age was 33 years (range: $20-53$ ). 
Training exercises ${ }^{\mathrm{a}}$ and symptom onset for cases $(\mathrm{n}=8)$, leptospirosis outbreak among canyoning participants, Martinique, 2011

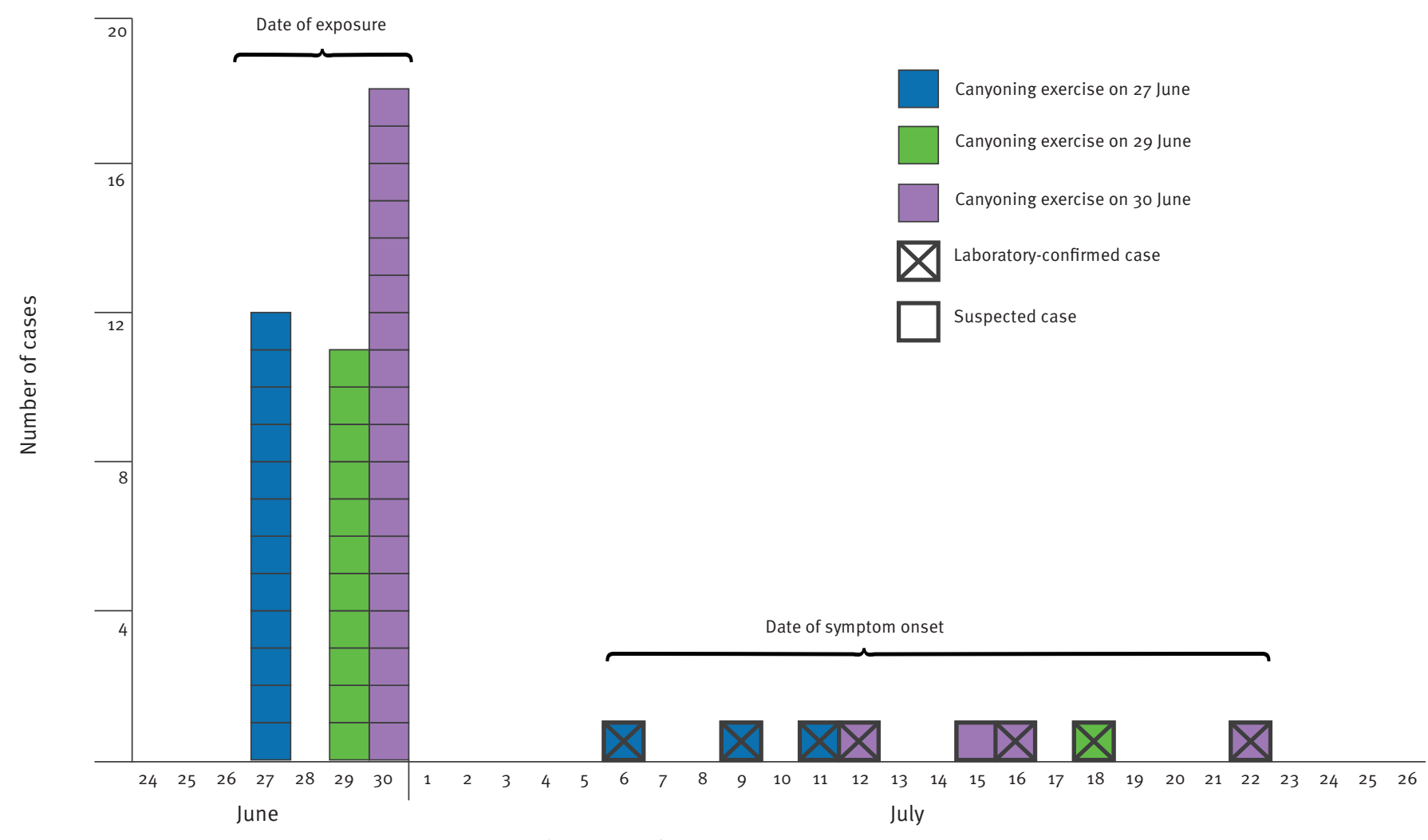

Date (month 2011)

Information from 41 participants who completed a questionnaire.

All participants who returned a completed questionnaire were French: 30 lived in Martinique and 11 came from a metropolitan region in mainland France. The median length of time spent in Martinique, for the 26 respondents for whom the information was available, was 1.27 years (range: $0.15-6.03$ ). Of the 45 participants, 16 had participated in the training exercises on 27 June, 11 on 29 June and 18 on 30 June 2011; four had participated in two of the exercises (on 27 and 30 June).

Among the 41 persons who returned a completed questionnaire, eight (attack rate 20\%) were suspected cases; their median age was 35.5 years (range: $23-53$ ). All eight were men; seven lived in Martinique and one in a metropolitan region in mainland France. We did not identify any participants who partly met the outbreak case definition (e.g. had fever but no other symptoms). Cases and non-cases were comparable by age, sex, place of residence and length of time spent in Martinique (data not shown).

The eight cases participated in only one of the three training exercises: three in that held on 27 June, one in that on the 29th and four in that on the 3oth (dayspecific attack rates of $19 \%(3 / 16), 9 \%(1 / 11)$ and $22 \%$ (4/18), respectively).

Of the eight cases, fever onset was clustered from 6 to 22 July (Figure). The median incubation period, determined from each participant's specific day of canyoning activities, was 14.5 days (range: 9-22). The eight cases sought medical attention at a median of 1.5 days (range: 0-6) after symptom onset. Beta-lactam antibiotics were prescribed for all eight; two were hospitalised for three days. No severe manifestations of leptospirosis were reported. The most common symptoms reported by the eight patients were: fever $(n=8)$, asthenia $(n=7)$, chills $(n=7)$, headache $(n=6)$, muscle aches $(n=6)$, nausea $(n=4)$, joint pain $(n=3)$ and conjunctival suffusion $(n=1)$. At admission, three had elevated liver enzyme or bilirubin levels, two were thrombocytopenic, one had leukocytosis and serum creatinine was elevated in one. C-reactive protein, with a median of $79 \mathrm{mg} / \mathrm{L}$ (range: 12-237), was high in all eight patients (norm: 1-10 mg/L). 
Univariate analysis of investigated factors associated with confirmed $(n=7)$ or suspected $(n=1)$ cases, leptospirosis outbreak among canyoning participants, Martinique, 2011

\begin{tabular}{|c|c|c|c|c|c|c|}
\hline \multirow{2}{*}{ Risk or protective factor } & \multicolumn{2}{|c|}{$\begin{array}{l}\text { Number who responded } \\
\text { to the particular question }\end{array}$} & \multicolumn{2}{|c|}{ Number who answered yes } & \multirow{2}{*}{$\begin{array}{l}\text { Relative risk } \\
\quad(95 \% \mathrm{Cl})\end{array}$} & \multirow{2}{*}{$P$ value } \\
\hline & $\begin{array}{c}\text { Cases } \\
n=8\end{array}$ & $\begin{array}{c}\text { Non-cases } \\
n=33\end{array}$ & $\begin{array}{c}\text { Cases } \\
n=8\end{array}$ & $\begin{array}{c}\begin{array}{c}\text { Non-cases } \\
n=33\end{array} \\
\end{array}$ & & \\
\hline Swallowed river water & 4 & 23 & 3 & 10 & $3.23(0.38-27.3)$ & 0.326 \\
\hline Had skin abrasions & 6 & 28 & 3 & 12 & $1.27(0.30-5.40)$ & 1.000 \\
\hline Wore neoprene suit ${ }^{\mathrm{b}}$ & 8 & 33 & o & 4 & - & 0.569 \\
\hline
\end{tabular}

a A total of 41 participants, including the eight cases, completed the questionnaire.

b Complete neoprene diving suits.

None of the eight cases reported any other canyoning or other potential exposure during leisure or professional activities during the month preceding the training exercises. In a univariate analysis, none of the potential risk or protective factors investigated was significantly associated with leptospirosis (Table 2). Finally, only 15 of the 33 respondents who answered the particular question declared having some knowledge of leptospirosis before the canyoning exercises.

\section{Laboratory investigation}

Serum samples were obtained from the eight participants who met the suspected case definition, with a median of two days (range: 0-6) after symptom onset. Acute- and convalescent-phase serum specimens were obtained from only two patients (Cases 4 and 7 ).
Leptospira infection was confirmed by qPCR in seven of the eight cases (Table 3). ELISA was also positive for three cases (Cases 1, 2 and 7). The acute-phase serum specimen from Case 6 had a negative ELISA and MAT.

Leptospira cultures were negative for two patients tested (Cases 4 and 8). For the other patients, by the time we had the diagnosis, they had received antibiotics, after which point culture is usually not possible.

Sequencing of the Leptospira 16S rDNA gene indicated that four cases (Cases 2, 3, 7 and 8) were infected with three genomospecies: L. santarosai (two cases), L. kmetyi and L. kmetyi-like. MAT of Case 1's isolate showed agglutination with the serogroup Celledoni.

TABLE 3

Laboratory results for leptospirosis outbreak among canyoning participants, Martinique, $2011(\mathrm{n}=8)$

\begin{tabular}{|c|c|c|c|c|c|}
\hline Case number & $\begin{array}{c}\text { Date of sampling in } 2011 \\
\text { (number of days after symptom onset) }\end{array}$ & $\mathrm{qPCR}$ & ELISA titre & $\begin{array}{l}\text { MAT titre } \\
\text { (serogroup) }\end{array}$ & $\begin{array}{l}\text { Genomic } \\
\text { species }\end{array}$ \\
\hline 1 & 10 July (4) & Positive & 6,400 & 400 (Celledoni) & ND \\
\hline 2 & 10 July (1) & Positive & 400 & 50 (Patoc) & L santarosai \\
\hline 3 & 13 July (2) & Positive & NT & NT & L. kmetyi-like a \\
\hline 4 & 18 July (o) & Positive & 0 & 0 & ND \\
\hline 5 & 18 July (2) & Positive & NT & NT & ND \\
\hline 6 & 19 July (4) & Negative & 0 & 0 & NT \\
\hline 7 & 18 July (6) & Positive & 1,600 & 800 (Patoc) & L. kmetyi ${ }^{\mathrm{b}}$ \\
\hline 8 & 23 July (1) & Positive & 0 & 0 & L santarosai \\
\hline
\end{tabular}

ELISA: enzyme-linked immunosorbent assay; MAT: microscopic agglutination test; ND: not determined; NT: not tested; qPCR: quantitative realtime polymerase chain reaction.

Sequencing of the 279 nucleotide 16 S rRNA PCR product showed similarity to L. kmetyi (273/279 nucleotides) and L. kirschneri (272/279 nucleotides).

b The 279 nucleotide 16S rRNA PCR product was identical except for two mismatches (277/279 nucleotides) to the corresponding variable region of the $16 \mathrm{~S}$ rRNA sequence of the $L$. kmetyi reference strain 


\section{Environmental investigation}

We obtained two sets of water samples from the river where the canyoning took place. All the cultures and the qPCR assays were negative or could not be analysed because of the presence of inhibitors, despite numerous filtrations to remove environmental contaminants.

According to Météo France, the total rainfall recorded in the main lowland of Martinique (which is the nearest place for rainfall recording) during the first six months of 2011 was the highest since 1981 [18]. Moreover, heavy rainfall was recorded in late June. At the same time, the temperatures recorded in June 2011 were the highest since 1971 , with a mean maximum of $32.1^{\circ} \mathrm{C}$ in the lowland [18].

\section{Discussion}

\section{Epidemiology and risk factors}

On the basis of our epidemiological investigation, exposure to Absalon River water was the most likely source of Leptospira infection. The attack rate of $20 \%$ could be explained by a combination of factors, such as: prolonged immersion in water, causing softening and wrinkling of the skin; unavoidable skin and mucous membrane exposure; and probably a higher concentration of leptospires in the river after the unusually heavy rainfall and high temperatures at the end of June. The investigation was conducted as part of a public health response and therefore laboratory analysis was carried out only on samples from symptomatic participants. However, these patients might represent only a small percentage of the infections, as in the majority of persons infected with leptospires, the infection remains subclinical and undiagnosed $[8,11]$. In previous leptospirosis outbreaks following exposure during recreational water activities, observed attack rates ranged from $12 \%$ to $42 \%[1,2,4,5]$.

Although none of the potential risk or protective factors investigated was significantly associated with leptospirosis, it should be noted that: (i) the response rate for some questions was low; (ii) those who reported having swallowed river water had three times the risk of developing leptospirosis compared with those who did not, although it remained not significant; (iii) 15 of 34 respondents reported having skin wounds during the canyoning exercises; and (iv) only four participants reported wearing complete neoprene suits that protected their arms and legs: none of them developed leptospirosis.

Together with being submerged in water, swallowing water potentially contaminated by leptospires was demonstrated to be a risk factor for leptospirosis among military personnel participating in several sporting events, in Okinawa, Japan, and persons drinking water from an Italian fountain $[2,4,5,19,20]$. In the outbreak reported here, Leptospira might also have been contracted via exposure of the conjunctivae and wrinkled, softened skin, as described in other water sports [3].

Although it has been described in recreational settings, leptospirosis in military personnel is mainly an occupational disease and outbreaks have been reported after training exercises in various areas, such as the high jungle rainforest of Peru, Japan, and northern Israel near the Jordan River [21-23]. As reported for other outbreaks related to military training exercices or sports events, young men in the Martinique outbreak reported here were predominantly affected $[2,4-6]$. However, the numbers of persons potentially exposed were low, comprising only a few women. None of those who wore protective clothing were women.

The presence of inhibitors in the PCR and cultures, or a bacterial load below the detection threshold, could explain the negative results obtained for environmental samples. Environmental investigations of other leptospirosis outbreaks (in which lake, creek and swamp water were sampled) in Illinois and Florida in the United States, samples tested negative, despite epidemiological evidence of widespread leptospiral contamination of the water and the surrounding environment $[2,5]$. As reported by Morgan et al., results of screening large bodies of freshwater for leptospires should not guide public health authorities in making decisions regarding the safe recreational use of water [2].

The end of June, 2011, when the canyoning exercises took place, was characterised by unusually heavy rainfall and high temperatures. In the Caribbean, as in other parts of the world, leptospirosis outbreaks have been reported after periods of heavy rainfall, flooding, and hurricanes $[24,25]$. In tropical areas where leptospirosis is endemic, it is thought that heavy rain or flooding saturates the potentially contaminated soil and the rising water level carries pathogenic leptospires to the surface of the land and rivers [7]. Outbreaks specifically associated with endurance and water sports events following periods of heavy rainfall have been reported in Costa Rica, the United States, Malaysian Borneo and Martinique [1,2,4-6].

\section{Laboratory aspects}

Blood samples for qPCR-based diagnosis were collected after a median of two days after symptom onset. As the qPCR assay used can be completed in around five hours (data not shown), information about the specific risk of leptospirosis was given to all participants within one week after confirmation of the first cases. In the context of an outbreak, MAT confirmation can be impeded by the absence of convalescent-phase samples, the need for reference laboratories, or the lack of sensitivity for region-specific serovars not represented in the test's antigen battery.

As we previously reported for a sporting event in Martinique, direct qPCR allows an unequivocal diagnosis based on a single specimen during the early acute 
phase of illness - when treatment is most effective and before serological and/or culture results become available $[6,7,26,27]$. Real-time PCR assays are being used increasingly to diagnose leptospirosis [28]. A recent study using a well-characterised cohort of laboratory-confirmed leptospirosis patients in Sri Lanka demonstrated not only the strength of the qPCR assay for early diagnosis, but also that the GPCR window of positivity ranged from day 2 to day 15 after symptom onset [29].

In the same samples used for qPCR-based diagnosis, we identified three Leptospira species. The identification of three different Leptospira species by sequencing could suggest multiple exposures in a risky environment, reflecting the diversity of potential wild and domestic reservoir animals in tropical areas. During 2010 to 2011, MAT on human serum samples showed that the most prevalent Leptospira serogroups in Martinique were Icterohaemorrhagiae (36\%), Sejroe $(16 \%)$, Ballum (12\%), Canicola (12\%), and Pyrogenes (8\%) (data from the National Reference Center for Leptospirosis, France). In our study, blood samples were collected during the first week of the disease, and only two cases' convalescent samples were available for conclusive testing. Therefore, despite the availability of a regionally optimised MAT panel, only one serogroup was identified.

As culture usually has a low sensitivity, it was not surprising that the results were negative. Moreover, the 1:10 dilution we used for culture may have impaired the technique.

\section{Prevention}

Following this leptospirosis outbreak in Martinique, health authorities informed all the organisers of canyoning activities on the island about the risk of leptospirosis and the need to inform participants about preventive measures [30]. Considering the inevitability of water exposure during canyoning activities and the higher risk of leptospirosis in tropical areas, all participants should be informed about individual preventive measures $[1,3]$. Preventive measures for participants in high-risk water activities in military or civilian settings are summarised in the Box. In our study, known risk factors, such as swallowing river water or skin abrasions, were not significantly associated with leptospirosis, but we may not have had sufficient data to detect significance. We can only hypothesise that the use of protective neoprene suits during canyoning might be protective. After a leptospirosis outbreak in workers who participated in cleaning a pond in Thailand, an investigation found that clothing was protective, while the presence of skin wounds was associated with infection, confirming that breaks in the skin serve as portals of entry for the leptospires [12].

None of the leptospirosis vaccines currently available is associated with protection against the wide diversity of serovars encountered in the tropics. The vaccine

\section{Box}

Recommendations regarding high-risk water activities in places such as rivers, lakes or swamps: what to do before, during and after the activities in order to prevent and promptly treat leptospirosis

\section{Before}

When possible, avoid any water activities the days following heavy rainfall and/or flooding.

\section{During}

Prevent skin abrasions by wearing appropriate clothes (e.g. protective neoprene suits during canyoning), avoid mucous membrane exposure when possible and avoid swallowing the water.

\section{After}

Rinse any abrasions or lacerations with clean water and antiseptics. Seek medical attention if fever occurs during the three weeks following the water activities.

available in France confers protection only against the serovar Icterohaemorrhagiae. The role of such immunisation to prevent leptospirosis in people who participate regularly in water activities in endemic areas warrants further study. To the best of our knowledge, this could be the first identification of $L$. kmetyi infection in humans, although this finding needs confirmation by genomic identification based on a positive culture.

For residents and travellers who visit endemic areas participating in recreational activities with prolonged water exposure, leptospirosis could theoretically be prevented by antibiotic chemoprophylaxis. The potential protective effect of antibiotics could not be assessed in our study because none of the participants reported any ongoing or recent antibiotic treatment. To date, three randomised clinical trials evaluated whether the use of doxycycline can prevent leptospirosis, either as pre-exposure (weekly administration) or post-exposure (single dose) prophylaxis. Taken together, the data does not support such prophylaxis in all cases, although short-term travellers with highrisk exposure may be helped [31-34]. To date, neither prophylaxis schedule has been evaluated in the setting of sporting events in the tropics. On the basis of the high leptospirosis attack rate among athletes who participated in an endurance race in Borneo in 2000, the United States Centers for Disease Control and Prevention recommended that all ill athletes be treated empirically with doxycycline and that asymptomatic athletes discuss the possible merits of a single doxycycline dose for post-exposure prophylaxis [4]. In the outbreak in Martinique reported here, no such chemoprophylaxis was offered, but participants were advised to seek medical attention and testing with rapid diagnostic assays to confirm the diagnosis and hence treat leptospirosis early during the disease course. 


\section{Acknowledgements}

We thank Janet Jacobson for editorial assistance and the technicians from the National Reference Center for Leptospirosis (Sylvie Brémont, Annie Landier and Farida Zinini) for serological analysis of sera. This work was funded by the Institut Pasteur and the French Institute for Public Health Surveillance (InVS).

\section{References}

1. From the Centers for Disease Control and Prevention. Outbreak of leptospirosis among white-water rafters--Costa Rica, 1996. JAMA.1997;278(10):808-9.

http://dx.doi.org/10.1001/jama.1997.03550100030014

2. Morgan J, Bornstein SL, Karpati AM, Bruce M, Bolin CA, Austin CC, et al. Outbreak of leptospirosis among triathlon participants and community residents in Springfield, Illinois, 1998. Clin Infect Dis. 2002;34(12):1593-9. http://dx.doi.org/10.1086/340615 PMid:12032894

3. Haake DA, Dundoo M, Cader R, Kubak BM, Hartskeerl RA, Sejvar J,, et al. Leptospirosis, water sports, and chemoprophylaxis. Clin Infect Dis. 2002;34(9):e40-3.

4. Sejvar J, Bancroft E, Winthrop K, Bettinger J, Bajani M, Bragg $\mathrm{S}$, et al. Leptospirosis in "Eco-Challenge" athletes, Malaysian Borneo, 2000. Emerg Infect Dis. 2003;9(6):702-7.

http://dx.doi.org/10.3201/eido906.020751 PMid:12781010 PMCid:3000150

5. Stern EJ, Galloway R, Shadomy SV, Wannemuehler K, Atrubin D, Blackmore C, et al. Outbreak of leptospirosis among Adventure Race participants in Florida, 2005. Clin Infect Dis. 2010;50(6):843-9.

http://dx.doi.org/10.1086/650578

PMid:20146629

6. Hochedez P, Rosine J, Théodose R, Abel S, Bourhy P, Picardeau $M$, et al. Outbreak of leptospirosis after a race in the tropical forest of Martinique. Am J Trop Med Hyg. 2011;84(4):621-6. http://dx.doi.org/10.4269/ajtmh.2011.10-0502 PMid:21460020 PMCid:3062459

7. Faine S, Adler B, Bolin CA, Perolat P. Leptospira and leptospirosis. 2nd ed. Melbourne: MediSci; 1999.

8. Levett PN. Leptospirosis. Clin Microbiol Rev. 2001;14(2):296326. http://dx.doi.org/10.1128/CMR.14.2.296-326.2001 PMid:11292640 PMCid:88975

9. Bharti AR, Nally JE, Ricaldi JN, Matthias MA, Diaz MM, Lovett MA, et al. Leptospirosis: a zoonotic disease of global importance. Lancet Infect Dis. 2003;3(12):757-71. http://dx.doi.org/10.1016/S1473-3099(03)00830-2

10. World Health Organization (WHO). Human leptospirosis: guidance for diagnosis, surveillance and control. Geneva: WHO; 2003. Available from: http://whqlibdoc.who.int/ hq/2003/WHO_CDS_CSR_EPH_2002.23.pdf

11. Ashford DA, Kaiser RM, Spiegel RA, Perkins BA, Weyant RS, Bragg SL, et al. Asymptomatic infection and risk factors for leptospirosis in Nicaragua. Am J Trop Med Hyg. 2000;63(5-6):249-54.

12. Phraisuwan $P$, Whitney EA, Tharmaphornpilas $P$, Guharat S, Thongkamsamut S, Aresagig S, et al. Leptospirosis: skin wounds and control strategies, Thailand, 1999. Emerg Infect Dis. 2002;8(12):1455-9.

http://dx.doi.org/10.3201/eido812.020180 PMid:12498663 PMCid:2738501

13. Vinetz JM. A mountain out of a molehill: do we treat acute leptospirosis, and if so, with what? Clin Infect Dis. 2003;36(12):1514-5. http://dx.doi.org/10.1086/375275 PMid:12802749

14. Brett-Major DM, Coldren R. Antibiotics for leptospirosis. Cochrane Database Syst Rev. 2012;2:CDoo8264.

15. Merien F, Portnoi D, Bourhy P, Charavay F, Berlioz-Arthaud A, Baranton $G$. A rapid and quantitative method for the detection of Leptospira species in human leptospirosis. FEMS Microbiol Lett. 2005 1;249(1):139-47.

16. Mérien F, Amouriaux P, Perolat P, Baranton G, Saint Girons I. Polymerase chain reaction for detection of Leptospira spp. in clinical samples. J Clin Microbiol. 1992;30(9):2219-24.

17. Postic D, Riquelme-Sertour N, Merien F, Perolat P, Baranton G. Interest of partial 16S rDNA gene sequences to resolve heterogeneities between Leptospira collections: application to L. meyeri. Res Microbiol. 2000;151(5):333-41. http://dx.doi.org/10.1016/S0923-2508(00)00156-X
18. Bulletin Climatique Mensuel. 972 Martinique. Juin 2011. [Monthly Climatic Bulletin. 972 Martinique. June 2011]. Météo France; 2011. Available from: http://www.meteo.gp/alaune/ bcm/archives/201106bcmmart.pdf

19. Corwin A, Ryan A, Bloys W, Thomas R, Deniega B, Watts D. A waterborne outbreak of leptospirosis among United States military personnel in Okinawa, Japan. Int J Epidemiol. 1990;19(3):743-8.

http://dx.doi.org/10.1093/ije/19.3.743

PMid:2262273

20. Cacciapuoti B, Ciceroni L, Maffei C, Di Stanislao F, Strusi P, Calegari L, et al. A waterborne outbreak of leptospirosis. Am Epidemiol. 1987;126(3):535-45.

21. Katz AR, Sasaki DM, Mumm AH, Escamilla J, Middleton CR, Romero SE. Leptospirosis on Oahu: an outbreak among military personnel associated with recreational exposure. Mil Med.1997;162(2):101-4.

22. Russell KL, Montiel Gonzalez MA, Watts DM, Lagos-Figueroa RC, Chauca G, Ore M, et al. An outbreak of leptospirosis among Peruvian military recruits. Am J Trop Med Hyg. 2003;69(1):53-7.

23. Hadad E, Pirogovsky A, Bartal C, Gilad J, Barnea A, Yitzhaki S, et al. An outbreak of leptospirosis among Israeli troops near the Jordan River. Am J Trop Med Hyg. 2006;74(1):127-31.

24. Sanders EJ, Rigau-Pérez JG, Smits HL, Deseda CC, Vorndam $\mathrm{VA}$, Aye T, et al. Increase of leptospirosis in dengue-negative patients after a hurricane in Puerto Rico in 1996 [correction of 1966]. Am J Trop Med Hyg. 1999;61(3):399-404.

25. Storck CH, Postic D, Lamaury I, Perez JM. Changes in epidemiology of leptospirosis in 2003--2004, a two El Ni-o Southern Oscillation period, Guadeloupe archipelago, French West Indies. Epidemiol Infect. 2008;136(10):1407-15. http://dx.doi.org/10.1017/S0950268807000052 PMid:18096102 PMCid:2870739

26. Merien F, Baranton G, Perolat P. Comparison of polymerase chain reaction with microagglutination test and culture for diagnosis of leptospirosis. J Infect Dis. 1995;172(1):281-5. http://dx.doi.org/10.1093/infdis/172.1.281 PMid:7797932

27. Levett PN, Morey RE, Galloway RL, Turner DE, Steigerwalt AG, Mayer LW. Detection of pathogenic leptospires by real-time quantitative PCR. J Med Microbiol. 2005;54(Pt 1):45-9.

28. Bourhy P, Bremont S, Zinini F, Giry C, Picardeau M. Comparison of real-time PCR assays for detection of pathogenic Leptospira spp. in blood and identification of variations in target sequences. J Clin Microbiol. 2011;49(6):2154-60. http://dx.doi.org/10.1128/JCM.02452-10 PMid:21471336 PMCid:3122738

29. Agampodi SB, Matthias MA, Moreno AC, Vinetz JM. Utility of quantitative polymerase chain reaction in leptospirosis diagnosis: association of level of leptospiremia and clinical manifestations in Sri Lanka. Clin Infect Dis. 2012;54(9):124955 . http://dx.doi.org/10.1093/cid/ciso35 PMid:22354922

30. Escher M, Hochedez P, Rosine J, Decoussy H, Pasgrimaud L, Martinez R, et al. Cas groupés de leptospirose chez les participants à des activités de canyoning en Martinique, 2011. [Outbreak of leptospirosis among canyoning participants, Martinique, 2011]. Bulletin de Veille Sanitaire, Cire Antilles Guyane. 2012;6:2-4. French. Available from: http://www.ars. martinique.sante.fr/fileadmin/MARTINIQUE/Votre Sante/ Veille_sanitaire/Les_champs_de_competences/BV̄S/BVS_12/ BVS_2012-06_V2.pdf

31. Takafuji ET, Kirkpatrick JW, Miller RN, Karwacki JJ, Kelley PW, Gray MR, et al. An efficacy trial of doxycycline chemoprophylaxis against leptospirosis. N Engl J Med. 1984;310(8):497-500.

http://dx.doi.org/10.1056/NEJM198402233100805 PMid:6363930

32. Gonsalez CR, Casseb J, Monteiro FG, Paula-Neto JB, Fernandez RB, Silva MV, et al. Use of doxycycline for leptospirosis after high-risk exposure in São Paulo, Brazil. Rev Inst Med Trop Sao Paulo.1998;40(1):59-61. http://dx.doi.org/10.1590/So036-46651998000100012 PMid: 9713140

33. Sehgal SC, Sugunan AP, Murhekar MV, Sharma S, Vijayachari P. Randomized controlled trial of doxycycline prophylaxis against leptospirosis in an endemic area. Int J Antimicrob Agents. 2000;13(4):249-55 http://dx.doi.org/10.1016/So924-8579(99)o0134-X

34. Brett-Major DM, Lipnick RJ. Antibiotic prophylaxis for leptospirosis. Cochrane Database Syst Rev. 2009;(3):CDo07342. 